\title{
Development of the recipe, technology of a functional fermented milk product with dill greens and «Dzhusay»
}

\author{
A.K.Stambekova ${ }^{1}$, A.A. Elemesova ${ }^{1}$ A.A. Bayakhan $^{1}, M$. K. Alimardanova ${ }^{1}$, \\ V. I. Petchenko ${ }^{1}$, and N.A. Levochkina ${ }^{2, *}$ \\ ${ }^{1}$ Almaty Technological University, 050012, 100, Tole bi str., Almaty, Kazakhstan \\ ${ }^{2}$ K.G. Razumovsky Moscow State University of Technologies and management (the First Cossack \\ University), 109004, 73, Zemlyanoy Val str., Moscow, Russian Federation
}

\begin{abstract}
The article considers the chemical composition and properties of vegetable fillers - dill and jusay, for the development of the formulation and technology of a new type of fermented milk product. Experimental data on the composition and luminescent characteristics of the developed product are presented.
\end{abstract}

\section{Introduction}

The purpose of the work is to develop a recipe, technology, and determine the quality of a fermented milk product using local vegetable raw materials. The study was conducted in the laboratory of the Department of "Food Technology" of the Almaty Technological University.

"Jusay" is resistant to cold, is not demanding on the soil, care, pests, diseases bypass it. It is called: wild onion, Chinese, fragrant branched onion, sometimes field, or mountain garlic, or garlic onion, grows everywhere and on rocky areas.

The useful properties of "Jusay" are attractive: it improves blood formation, strengthens blood vessels, immunity, stimulates the production of gastric juice, the hormone testosterone in men, improves the functioning of the nervous system, has a choleretic, diuretic, antimicrobial effect, potassium regulates the water balance, and zinc helps to strengthen hair, improve the structure of the skin, and strengthens teeth. It is recommended for infectious diseases (tuberculosis), pneumonia, and the cardiovascular system, including burns from nettle, insect bites, skin injuries, and bleeding. So, the caloric content of Jusay per $100 \mathrm{~g}$ is $40-41 \mathrm{kcal}$, the composition includes, in \%: carbohydrates 8.2-8.4; proteins 1.4-1.5; fats-0.2; water-91-92; dietary fiber $0.8-0.9$; ash substances $0.3-0.35$. Its vitamin composition, in $\mathrm{mg}$ : beta-carotene-about 1; C-4.8; B5-0.1; B3-0.28; B6-0.13; alphatocopherol-0.02; there are vitamins K, B1, B2 and B9. Mineral content, in mg: K-120-123; Na-27-29; Ca-19-22; Md-8.5-9.5; Fe-0.26-0.28; Zn-0.12-0.15; Mp-0.08; in mcg Se-0.5; $\mathrm{Cu}-0.06$. [1].

\footnotetext{
${ }^{*}$ Corresponding author: omsk@mgutm.ru
} 
When developing the recipe, the technology of the fermented milk product with dill and jusay was based on "Ayran" of low fat content of $1 \%$ of the manufacturer "Adal". Based on preliminary experiments, the following research options were selected: experiment 1-Ayran (100 ml everywhere) $+20 \mathrm{~g}$ of finely ground dill $+5 \mathrm{~g}$ of finely ground dill; experience 2 Ayran $+20 \mathrm{~g}$ of finely ground dill $+7 \mathrm{~g}$ of finely ground dill; experience 3 -Ayran $+20 \mathrm{~g}$ of finely ground dill $+10 \mathrm{~g}$ of finely ground dill.

\section{Methods}

Dill (greens) - caloric content and chemical composition per $100 \mathrm{~g}$ are as follows, in $\mathrm{g}$ : caloric content - $40 \mathrm{kcal}$, protein-2.5; fat-0.5; carbohydrates-6.3; fiber-2.8; organic acids0.1 ; glycemic index-10. Vitamins, in mg: B1-0.03; B2-0.1; C -100; E-1.7; B3, PP-1.4; B50.25; B6 -0.15; in mcg: B9-27; A (retinol equivalent)-750 (covers the daily requirement, respectively, in $\%$ for $2 ; 6 ; 143 ; 17 ; 7 ; 5 ; 8 ; 7 ; 75)$. Minerals, in mg: K-335; Ca-223; Md70; P-93; Na-43; Fe-1,6; Zn-0,91; Mp-1,26; in mcg: Si-146 (provides the daily requirement of the human body, respectively, in $\%$ on: $13 ; 22 ; 18 ; 9 ; 3 ; 11 ; 8 ; 63 ; 15)$.[2].

\section{Results and discussion}

Ayran $1 \%$ fat content-has a white color, a liquid homogeneous consistency with bubbles, the taste is moderately sour, slightly spicy, the calorie content is $37-40 \mathrm{kcal}$ per $100 \mathrm{~g}$, depends on the method of preparation. Nutritional value, chemical composition of the drink "Ayran" $1 \%$, in g per $100 \mathrm{~g}$ : calories-27 kcal, protein-1.74; fat-1; lactose-2.79. The amino acid composition includes all essential and non-essential amino acids. Vitamin composition - vitamins A, B1, B2, B4, B5, B6, B9, B12, PP, H, E, D. The mineral composition contains $\mathrm{K}, \mathrm{Na}, \mathrm{Ca}, \mathrm{Fe}, \mathrm{Zn}, \mathrm{F}, \mathrm{P}, \mathrm{Se}, \mathrm{Cu}, \mathrm{Ng}$.

Preliminary preparation of the ingredients was carried out. previously, the greens were subjected to primary processing, slicing (crumbs). The mixture was mixed and kept for 1015 minutes.

Analysis of the fermented milk drink "Ayran" $1 \%$ showed that when adding iodine, starch is absent (Figure 1d), because the color of the indicator is the same. The consistency is liquid, homogeneous, clean, characteristic smell, sour-milk taste, white color is uniform by weight, $\mathrm{pH}$ is normal.

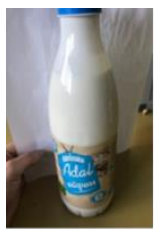

a

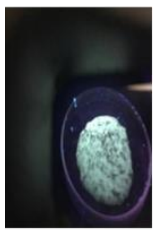

h

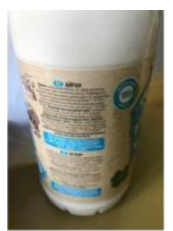

b

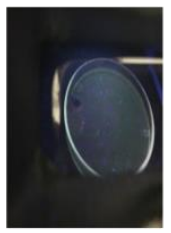

i

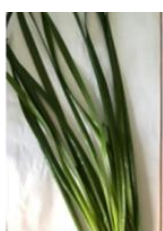

C

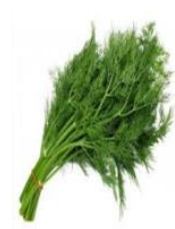

d

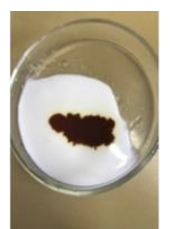

e

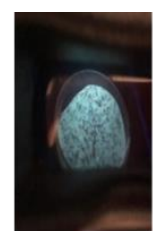

f

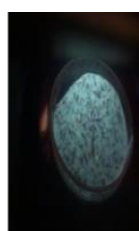

g

Fig.1. Quality characteristics of the ingredients of the fermented milk product. 


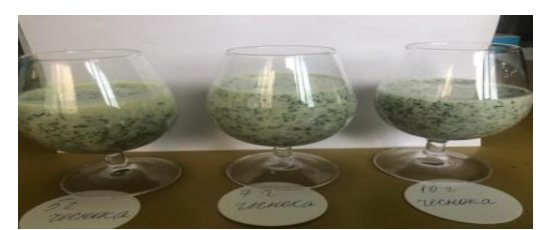

$\mathrm{a}-$ front view

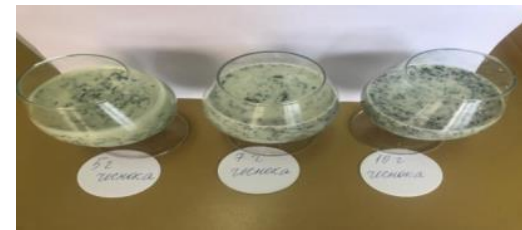

$\mathrm{b}-$ top view

Fig.2. Samples (experience 1-3) of fermented milk product.

Table 1. Organoleptic evaluation of experimental samples, dry matter content before and after drying of greens.

\begin{tabular}{|c|c|c|c|c|c|}
\hline Sample & $\begin{array}{l}\text { Appearance, } \\
\text { color }\end{array}$ & Smele & Taste & Consistensy & $\begin{array}{c}\text { Dry matter, } \\
\mathrm{g}_{-}\end{array}$ \\
\hline Ayran $1 \%$ control & $\begin{array}{l}\text { White, } \\
\text { uniform over the } \\
\text { entire mass }\end{array}$ & clean, $\mathrm{k} / \mathrm{m}$ & clean, $\mathrm{k} / \mathrm{m}$ & $\begin{array}{l}\text { liquid, } \\
\text { homogeneous }\end{array}$ & \begin{tabular}{|l|} 
before drying \\
37,933 \\
drying 35,833
\end{tabular} \\
\hline $\begin{array}{l}\text { 1.Ayran+ dill+ } \\
\text { Jusay } \\
5 \mathrm{~g}\end{array}$ & $\begin{array}{l}\text { light green } \\
\text { Ayran, green } \\
\text { inclusions of } \\
\text { additives }\end{array}$ & $\begin{array}{l}\text { sour milk, } \\
\text { weak garlic }\end{array}$ & $\begin{array}{l}\text { sour milk, it } \\
\text { feels like } \\
\text { garlic }\end{array}$ & $\begin{array}{l}\text { non-native } \\
\text { green inclusions }\end{array}$ & \begin{tabular}{|l} 
before drying \\
37,1342 \\
drying \\
37,1333
\end{tabular} \\
\hline $\begin{array}{l}\text { 2. Ayran + dill+ } \\
\text { Jusay } \\
7 \mathrm{~g}\end{array}$ & $\begin{array}{l}\text { greenish Ayran, } \\
\text { green inclusions } \\
\text { of } \\
\text { additives }\end{array}$ & $\begin{array}{l}\text { sour milk } \\
\text { weak } \\
\text { garlic- } \\
\text { night }\end{array}$ & $\begin{array}{l}\text { sour milk., } \\
\text { the } \\
\text { presence of } \\
\text { garlic is felt }\end{array}$ & $\begin{array}{l}\text { heterogeneous } \\
\text { interspersed with } \\
\text { dense } \\
\text { green }\end{array}$ & \begin{tabular}{|l} 
before drying \\
38.5811 \\
drying \\
38.5806
\end{tabular} \\
\hline $\begin{array}{l}\text { 3. Ayran+ dill+ } \\
\text { Jusay } \\
10 \mathrm{~g}\end{array}$ & $\begin{array}{l}\text { green with a blue } \\
\text { tinge, green } \\
\text { inclusions of the } \\
\text { additive }\end{array}$ & $\begin{array}{l}\text { sour milk, } \\
\text { weak garlic } \\
\text { flavor }\end{array}$ & $\begin{array}{l}\text { sour milk., } \\
\text { strongly } \\
\text { burning } \\
\text { taste of } \\
\text { garlic }\end{array}$ & $\begin{array}{l}\text { heterogeneous } \\
\text { green blotches, } \\
\text { thick }\end{array}$ & \begin{tabular}{|l} 
before drying \\
38,8693 \\
drying \\
38,8678
\end{tabular} \\
\hline
\end{tabular}

The data of the theoretical calculation of the developed formulations are presented in Table 2 .

Table 2. Recipe options, nutritional and energy value (EC) of the fermented milk product.

\begin{tabular}{|c|c|c|c|c|c|c|c|c|}
\hline \multirow{2}{*}{ Name } & \multirow{2}{*}{$\begin{array}{c}\text { net } \\
\text { weight, } \\
\text { g }\end{array}$} & \multicolumn{3}{|c|}{$\begin{array}{c}\text { per } 100 \mathrm{~g} \text { of raw } \\
\text { materials }\end{array}$} & \multicolumn{3}{|c|}{ per serving yield, $g$} & \multirow{2}{*}{$\begin{array}{c}\text { Energy } \\
\text { value } \\
\text { (kcal) }\end{array}$} \\
\hline & & Protein & Fat & $\begin{array}{c}\text { Carbo- } \\
\text { hydrate }\end{array}$ & Protein & Fat & $\begin{array}{l}\text { Carbo- } \\
\text { hydrate }\end{array}$ & \\
\hline \multicolumn{9}{|c|}{ Fermented milk product with the addition of herbs } \\
\hline $\begin{array}{l}\text { Ayran } 1 \\
\%\end{array}$ & 100 & 2,8 & 2,5 & 3,9 & 2,8 & 2,5 & 3,9 & 49,3 \\
\hline Dill & 20 & 16 & 15 & 55 & 3,2 & 3 & 11 & 83,8 \\
\hline Jusay & 5 & 6,5 & 0,5 & 29,9 & 0,325 & 0,025 & 1,495 & 7,505 \\
\hline Jusay & 7 & 6,5 & 0,5 & 29,9 & 0,455 & 0,035 & 2,093 & 10,507 \\
\hline Jusay & 10 & 6,5 & 0,5 & 29,9 & 0,65 & 0,05 & 2,99 & 15,01 \\
\hline $\begin{array}{l}\text { Yield } \\
\text { (sample } \\
\text { experience } \\
\text { 1) }\end{array}$ & 125 & & & & 6,325 & 5,525 & 16,395 & 140,605 \\
\hline
\end{tabular}




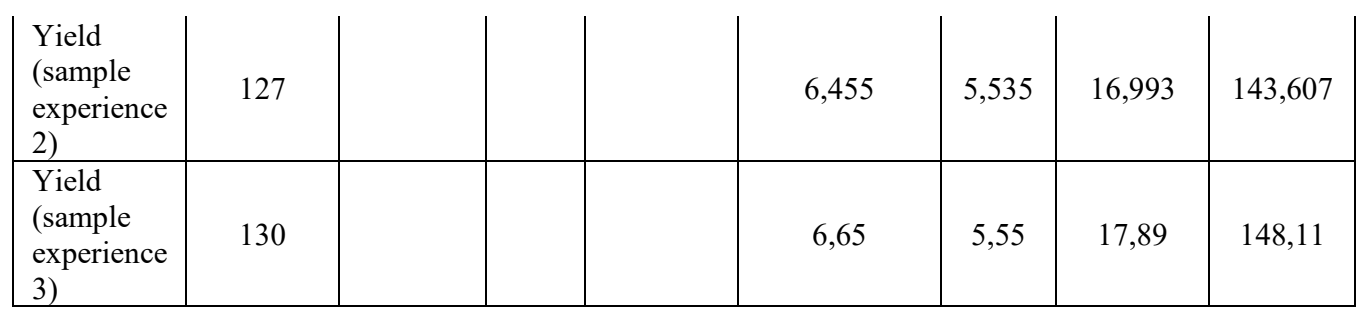

In Figure 1 (e, f, g) and 2 (a -front view and b-top view), different color intensity is observed, and more has changed in Experiment 3 (Figure 1, 2). Perhaps due to the acidity of the medium, the amount of 1:2 of "Jusay" greens (Figure 1), where it is $5 \mathrm{~g}$ (e) and twice as much as $10 \mathrm{~g} \mathrm{(h)}$, as well as the consistency of the fermented milk product is thicker, that is, practically the form did not spread (Figure 1h). In the device" Filin " test samples color, luminescence of the product trend is maintained, as well as in the filtrate (Fig. 1i)/

The use of greens in the fermented milk product (samples 1,2,3) positively affected the organoleptic parameters, the content of dry substances when compared with the control fermented milk drink "Ayran".

The increase in acidity contributed to the swelling of fiber, pectin substances of plant additives. The yield of the formulations corresponds to the standards (125-130g).

\section{Conclusion}

The yield of Ayran with vegetable fillers of the developed formulations meets the regulatory requirements, and new types of product can be recommended for public catering and dairy enterprises. The study of the quality and safety of the developed types of Ayran revealed their compliance with TR CU 033/2013 [4]. Other fermented milk products developed by us are also recommended to the enterprises of the dairy industry [5-6].

\section{References}

1. S. N. Udintsev, T. P. Zhilyakova, Vestn. Tomsk State University, Biology, 18, 2 (2012)

2. M. A. Subbotina, Bulletin of KuzSTU, 2 (2009)

3. M. Skurikhina, V. A. Tuteliana, Chemical composition of Russian food products: Handbook (Moscow, Delhi Print, 2002)

4. Operation manual ZHIGN 346.160.009 PS Luminoscope "Filin" (St. Petersburg, 2005)

5. Technical regulations of the Customs Union TR CU 033/2013 "On the safety of milk and dairy products" (2013)

6. V. I. Petchenko, M. K. Alimardanova, I. Bildibaeva, V. Pomogaeva, V. Sereshcheva, International scientific and practical conference "Actual problems of modern science2020"(Nur-Sultan, Kazconf media conference, 2020)

7. V. I. Petchenko, M. K. Alimardanova, A. Smagulova, A. Orazbek, International scientific and practical conference "Actual problems of modern science-2020" (NurSultan, Kazconf media conference, 2020)

8. N. A. Abakumova, N. N. Bykova, Organic chemistry and the basics of biochemistry (Tambov, GOU VPO TSTU, 2010)

9. Ya. Nikolaev, Biological Chemistry (Medical Information Agency, 2004)

10. V.B. Spirichev, Nutrition Issues, 5 (2010) 